\title{
Modelling the effects of trafficking and tamping on scaled railway ballast in triaxial tests
}

\author{
Authors: Sinthuja Aingaran ${ }^{1}$, Louis Le Pen ${ }^{2}$, Antonis Zervos ${ }^{2}$, William Powrie ${ }^{2}$ \\ ${ }^{1}$ Faculty of Technology, University of Jaffna, Ariviyal Nagar, Kilinochchi, Northern Province, \\ Sri Lanka \\ ${ }^{2}$ Infrastructure Research Group, Faculty of Engineering and the Environment, University of \\ Southampton, Southampton, SO17 1BJ, United Kingdom.
}

This author's non-typeset version of the article was accepted for publication by Transportation Geotechnics on 25 April 2018. An online ahead of print version is available at: https://doi.org/10.1016/j.trgeo.2018.04.004

All data supporting this study are openly available from the University of Southampton repository at https://doi.org/10.5258/SOTON/D0509

The reference for the online ahead of print version is:

- Aingaran, S., Le Pen, L., Zervos, A. \& Powrie, W. (2018 - OAP) Modelling the effects of trafficking and tamping on scaled railway ballast in triaxial tests. Transportation Geotechnics. https://doi.org/10.1016/j.trgeo.2018.04.004

When the in print version becomes available this will become the version of record.

\begin{abstract}
Most of the world's railways are on ballasted track, which is generally used in preference to slab track because of its lower initial cost and the relative ease with which track geometry can be adjusted. However, the accumulation of track movements as a result of trafficking leads to a gradual deterioration in track line and level, hence the need for periodic corrective maintenance. This is usually by tamping; a process in which the track is lifted and vibrating tines are inserted into the ballast and moved horizontally to raise the ballast surface back to the required level. The period before further maintenance is required decreases with each tamp. This paper investigates one of the reasons for the deterioration in ballast robustness following tamping, with reference to triaxial tests on scaled ballast in which vertical loading cycles and the stress reversal caused below the railseat by tamping were simulated. It is shown that the stress reversal disrupts and loosens the vertical load bearing ballast structure developed during trafficking to support vertical train loads. On reloading after tamping, the track settles significantly and, as a result of the loss of vertical load-bearing structure, with further load cycles rapidly returns to its reduced height. The implication is that maintenance by tamping is, on its own, disruptive to the structure and resilience of the ballast to vertical cyclic loading, and should be carried out as rarely as possible.
\end{abstract}




\section{Modelling the effects of trafficking and tamping on scaled railway ballast in triaxial tests}

\section{Introduction}

Most of the world's railways are on ballasted track; a situation that is likely to prevail for the foreseeable future not least because of the volume of the current asset base. Ballasted track is generally adopted in preference to slab track because of its lower initial cost and the relative ease with which track geometry may be changed. However, the accumulation of track movements as a result of trafficking leads to a gradual deterioration in track line and level. Deviations from the required line and level must be corrected through maintenance before they start to affect operational efficiency, passenger comfort or railway safety.

Maintenance to correct track geometry is usually carried out by tamping during overnight possessions (Figure 1). The track is lifted and vibrating tines are inserted into the ballast to squeeze the ballast horizontally, raising the ballast surface back to the required level. There are two primary mechanisms of motion present for the tamping tines. The first is a higher frequency vibratory motion of low amplitude taking place at up to $40 \mathrm{~Hz}$. This motion breaks the interparticle contact momentarily allowing the tines to be pushed into and through the ballast. The second motion is a larger amplitude squeezing motion as the tines are brought together beneath the railseat, raising up the surface height of the ballast in this location to bring the track level back to the intended position (Figure 2).

It is well-known that after each tamping cycle the ballast settles at a faster rate with trafficking and returns to its pre-maintenance profile sooner [1]. This is ascribed to a temporary loss of strength and stiffness (see e.g. [2 \& 3]) and/or a physical degradation related to the attrition of the ballast particles [4-6]. The initial loss of strength and stiffness may be addressed either by imposing a temporary speed restriction so that through the process of trafficking the ballast performance improves before higher speed trains, with their associated higher dynamic loading, are permitted; or more quickly through application of dynamic track stabilization techniques. It is also known that a tamping lift of at least the average ballast grain size $(\sim 40 \mathrm{~mm})$ is needed to show a lasting improvement in track geometry [1]. The attrition of the ballast particles may largely be attributed to the higher frequency $(\sim 40 \mathrm{hz})$ lower amplitude vibration of the tines, while the lift imposed is largely due to the larger amplitude, quasi-static squeezing motion of the tines. 


\section{Modelling the effects of trafficking and tamping on scaled railway ballast in triaxial tests}

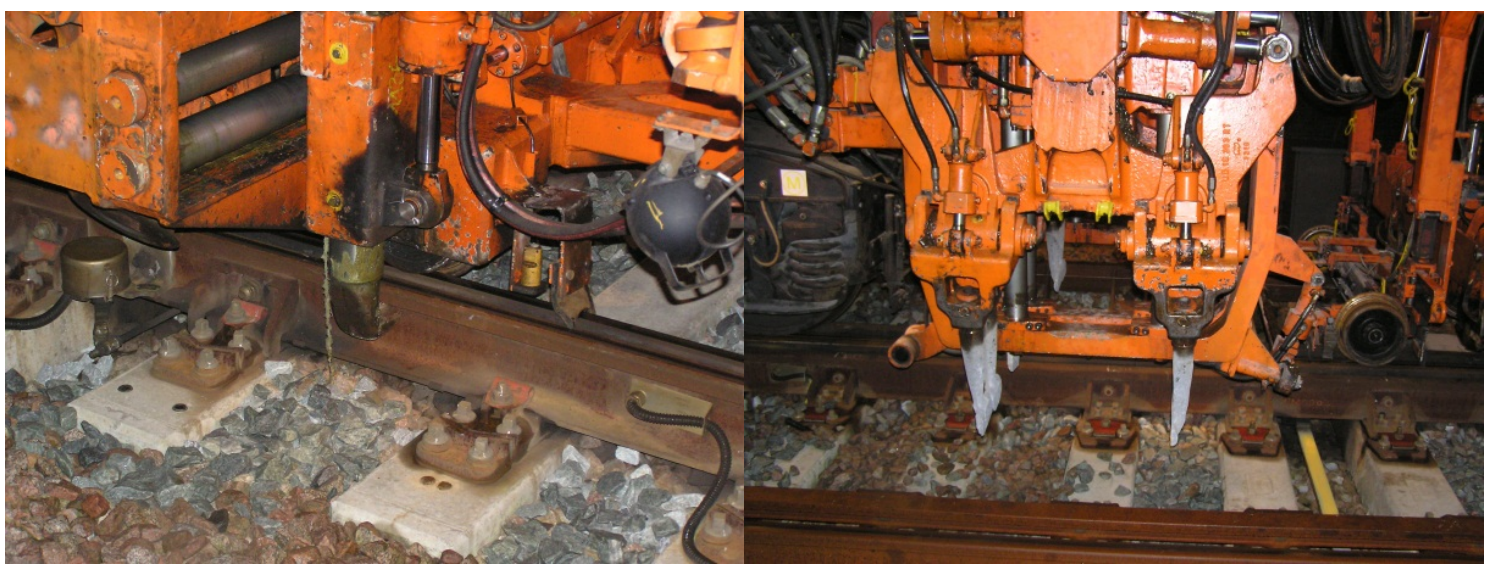

Figure 1: (a) track being lifted as tamping takes place next to a check rail (b) tamping tines removed from the ballast

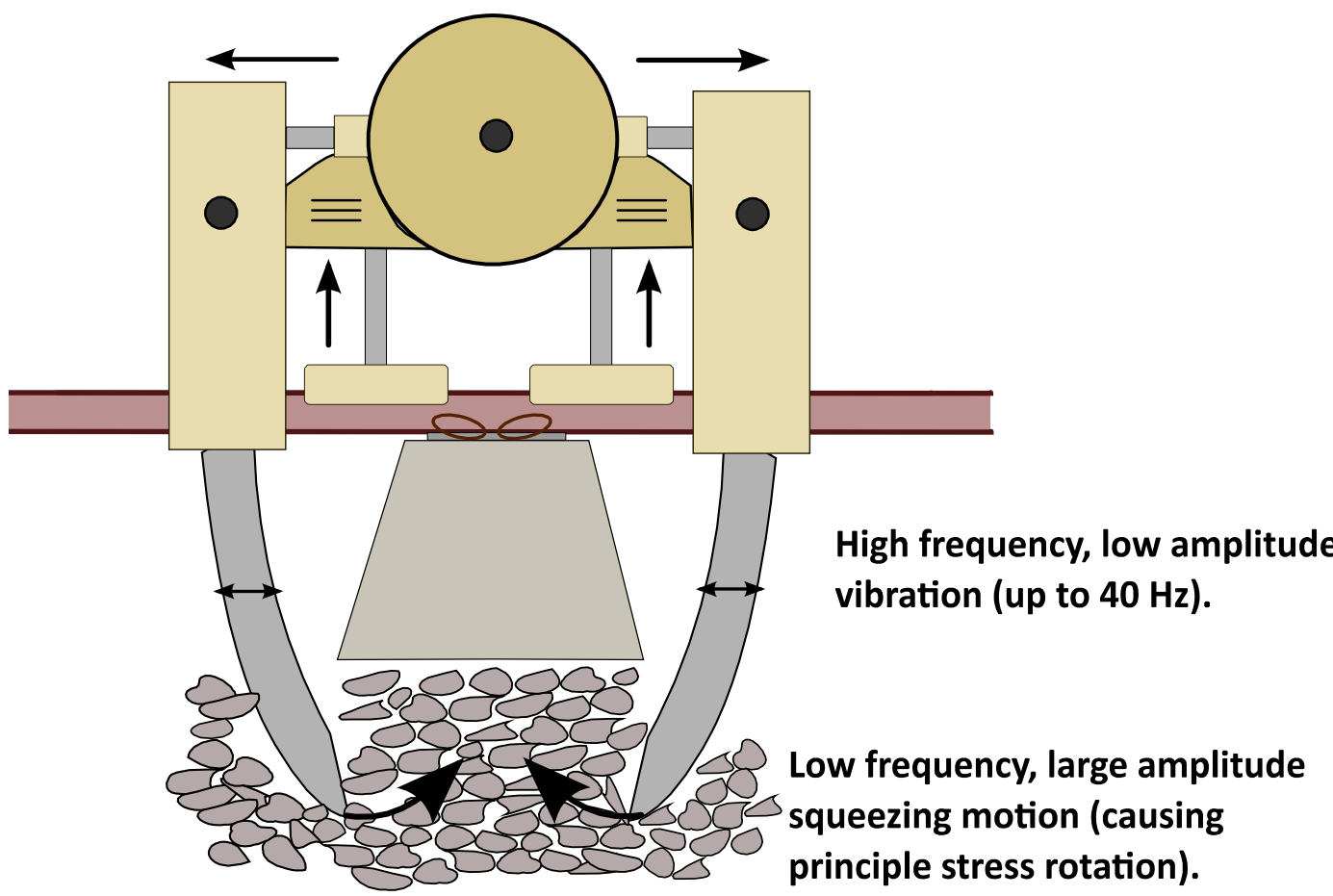

Figure 2: schematic to show the two main mechanisms of movement applied during tamping(modified after [7])

What does not seem to have been identified explicitly in the literature is the loss of ballast structure that tamping must inevitably cause. Fabric structure (i.e. the spatial arrangement of particles and associated voids) has a strong influence on the mechanical behaviour of natural soils (e.g. [8, 9, 10, 11, and 12]). Fabric is also increasingly being recognised as important in the behaviour of placed materials such as embankment fills [13]. Following initial placement, ballast structure develops with cumulative cycles of vertical load. These cause the ballast grains to settle and rearrange, thereby establishing relative positions suited to carrying the vertical loads imposed by trains with minimal or no further rearrangement. Tamping, by the application of essentially horizontal loads, establishes a 


\section{Modelling the effects of trafficking and tamping on scaled railway ballast in triaxial tests}

new structure no longer suited to carrying vertical external loads. Thus when vertical loading by trafficking resumes significant further rearrangement of the ballast structure and an accompanying deterioration of the track geometry are inevitable.

The work reported in this paper is based on a series of triaxial tests on scaled ballast specimens, in which cyclic vertical loading was interspersed with episodes of horizontal loading (i.e. a change in the direction of the major principal stress from vertical to horizontal), simulating the larger amplitude motion of the tines in squeezing the ballast beneath the railseat to raise the surface height.

\section{Background}

Railway ballast is a uniformly graded coarse aggregate with grains typically in the size range $20 \mathrm{~mm}$ to $65 \mathrm{~mm}$. It is generally accepted that the best quality ballast is formed of crushed igneous rock with high abrasion and fracture resistance [14], although some metamorphic and well cemented sedimentary rocks may also perform satisfactorily. Materials used in practice are often what is locally available, hence rock types used vary across the world.

Modern ballasted track generally has a minimum depth of ballast of $300 \mathrm{~mm}$ below the sleeper base placed on prepared subgrade whose characteristics depend on local conditions. This ballast depth may be reduced slightly in some circumstances but must remain sufficient for tamping tines to be inserted.

Previous work on the cyclic laboratory testing of railway ballast (e.g.[15-20]) has focused on the global mechanical properties of strength and stiffness in monotonic and cyclic vertical loading, with cyclic tests also investigating settlement. In general over stress cycles representative of train loading, settlement rates reduce as the number of load cycles increases. At the same time, the stiffness generally increases [21, 22]. However, at certain threshold values, either after a certain number of load cycles or when the stress path becomes more onerous, the settlement rate may increase. Most tests did not consider the effects of tamping.

\section{Materials and methods: Triaxial testing}

\subsection{Scaled ballast}

To avoid the need for very large specimens and associated testing apparatus, the triaxial tests were carried out on a 1/3 size parallel gradation [23] of a natural crushed granite ballast material mapped from a Network Rail standard ballast grading curve (Figure 3). Provided the scaled material is from the same parent rock as the full size material the scaled 


\section{Modelling the effects of trafficking and tamping on scaled railway ballast in triaxial tests}

material reproduces satisfactorily key aspects of grain shape (Figures 4 and 5) and, at least in monotonic tests the strength of the full size material [24-26]. There will remain some differences between the relative grain shape performance and mechanical properties of the $1 / 3$ size material and those of full size ballast. However, the use of $1 / 3$ size material gives insights into the trends of behaviour that may be expected at full size with the advantage that standard testing apparatus can be used and specimens more easily prepared.

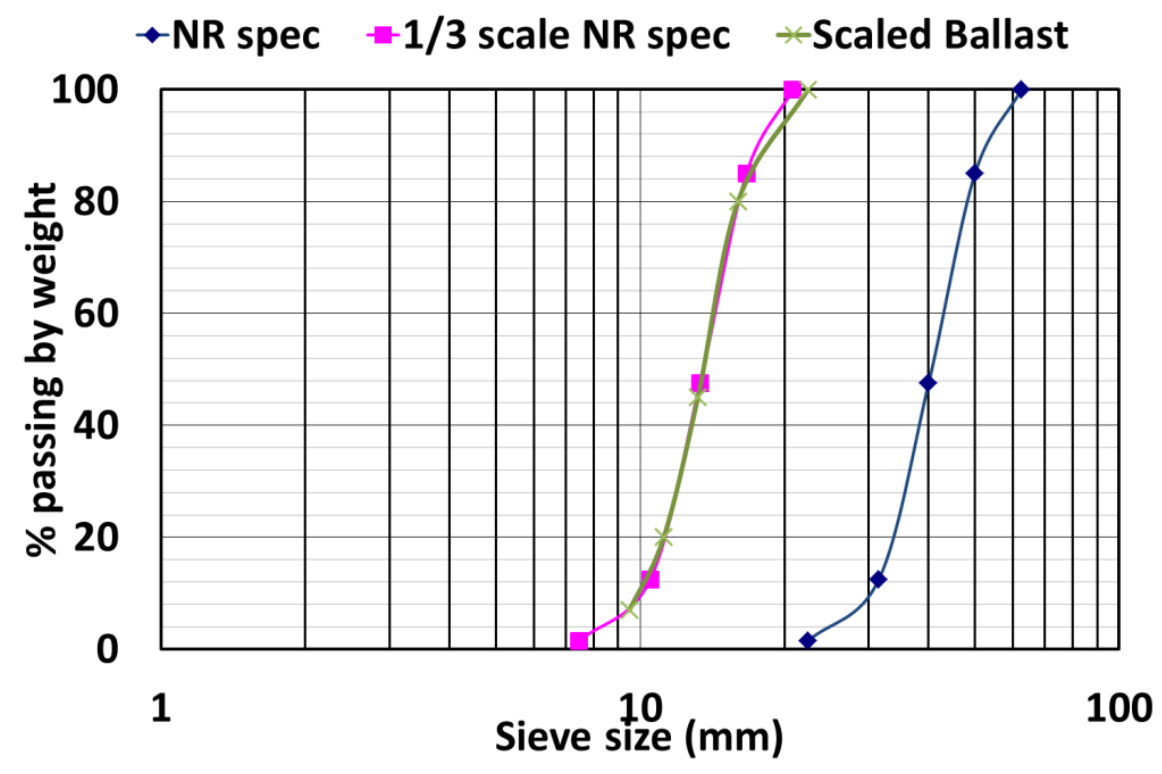

Figure 3: (a) Grain size distribution curves for full size and scaled ballasts

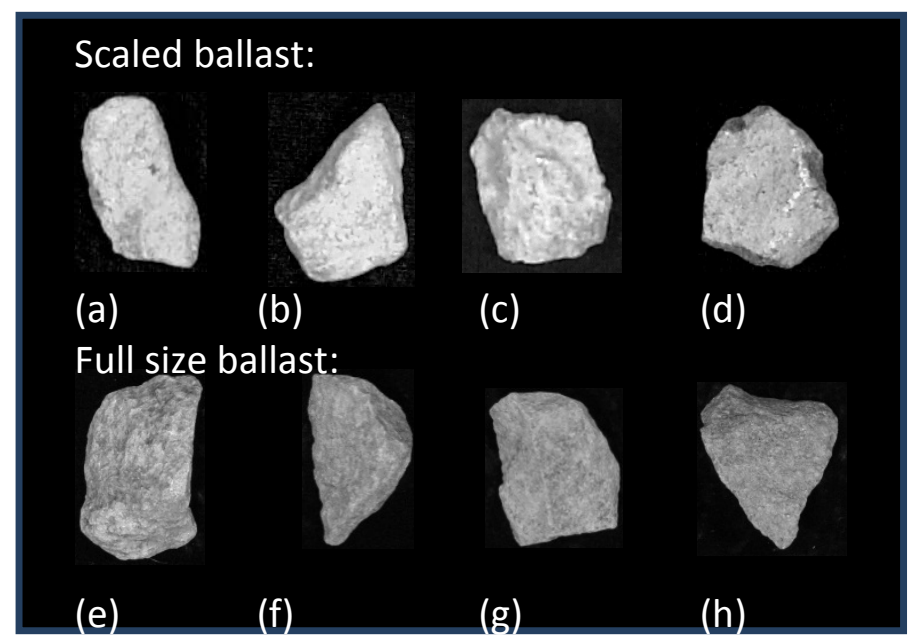

Figure 4: Example particles in sieve intervals (after [24]): (a) 9.5 to 11.2 (b) 11.2 to 13.2 (c) 13.2 to 16.0 , (d) 16.0 to 22.4 (e) 22.4 to 31.5 (f) 31.5 to 40.0 (g) 40.0 to 50.0 (h) 50.0 to 62.5 


\section{Modelling the effects of trafficking and tamping on scaled railway ballast in triaxial tests}

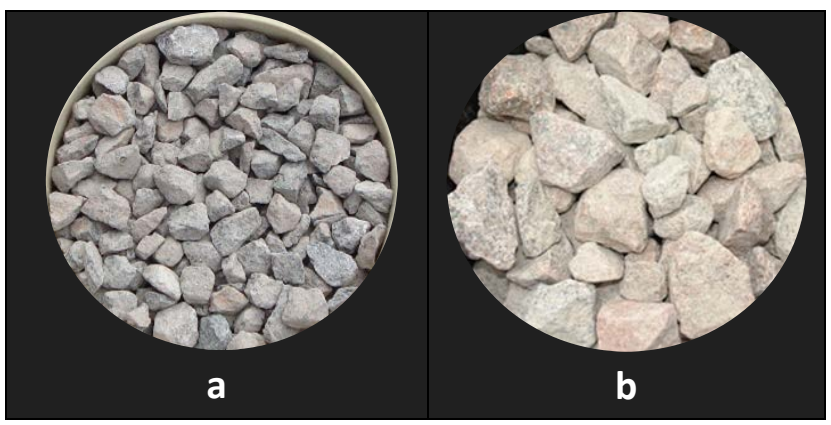

Figure 5: Comparison of (a) scaled ballast and (b) full size ballast, images approximately in correct size proportion

\subsection{Triaxial text apparatus}

The triaxial apparatus [27] shown in Figure 6 had the capacity to test cylindrical specimens $300 \mathrm{~mm}$ high and $150 \mathrm{~mm}$ in diameter. The specimen diameter to maximum grain size ratio $\left(D / d_{\max }\right)$ was more than $6(150 / 21=7.1)$, which is generally considered to be sufficient for the specimen to behave as a representative elemental volume with the effects of any individual grains being relatively negligible [28].

Simulation of the change in major principal stress direction caused by tamping required the application of a negative deviator stress to keep the vertical stress constant while the cell pressure was increased. To facilitate this, some modifications were to the standard apparatus were needed, including the use of a modified ball jointed top platen (Figure 7).

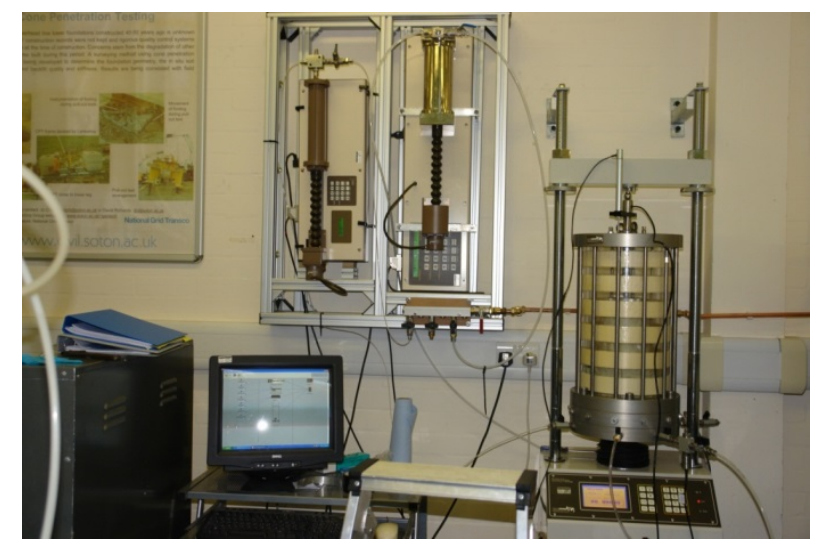

Figure 6: Triaxial testing apparatus 


\section{Modelling the effects of trafficking and tamping on scaled railway ballast in triaxial tests}

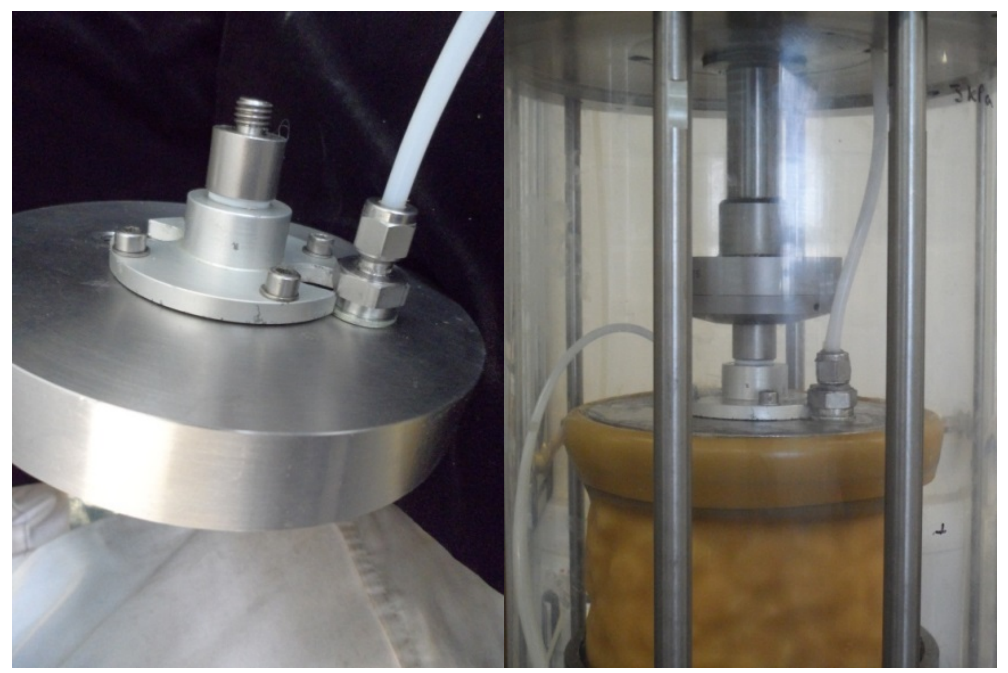

Figure 7: Top cap arrangement during extension test

\subsection{Specimen preparation}

A $2 \mathrm{~mm}$ thick latex membrane was pulled up inside and rolled over a split cell mould and held in place by O-rings at both the top and the bottom. A porous disc was placed at the bottom and held in place using flexible metal clips. The split mould was then filled with scaled ballast, placed in three layers. Each layer was vibrated for 1 minute under its own weight, followed by 1 minute with a $5 \mathrm{~kg}$ mass on top. The top of the specimen was levelled by placing individual grains by hand, followed by further vibration under self-weight.

These preparation methods resulted in specimens of similar bulk density (Table 1). The split mould containing the specimen was then transferred to the triaxial cell base and the metal clips were removed. The membrane was pulled over each end and secured using the two Orings (Figure 8a) with silicone grease used to maintain the seals. An internal suction of approximately $20 \mathrm{kPa}$ was maintained to prevent the specimen from slumping when the split cell mould was removed (Figure $8 \mathrm{~b}$ ). The cell was placed and filled with de-aired water, the air vents closed and the cell pressure applied. The internal specimen suction was then relaxed and a valve opened to connect the inside of the sample to atmospheric pressure. Finally the deviator stress was increased to the required initial value. 


\section{Modelling the effects of trafficking and tamping on scaled railway ballast in triaxial tests}

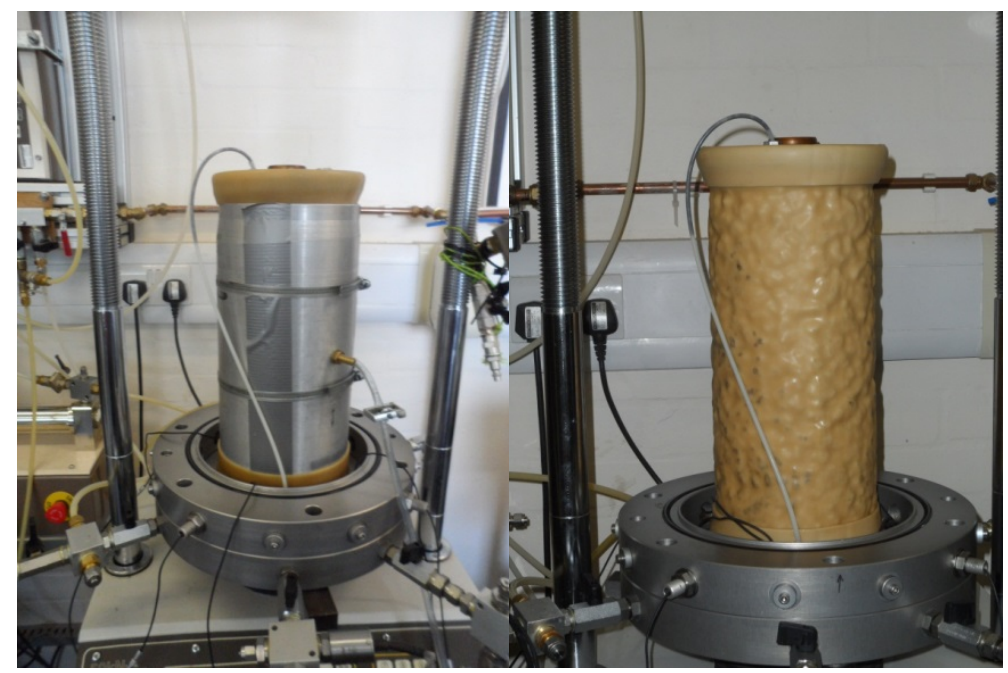

Figure 8: Triaxial test preparation: Specimen (a) in the split cell mould, and (b) under suction

\subsection{Triaxial test data}

The test results are evaluated in terms of:

- changes in specimen height with number of load cycles

- changes in resilient modulus with number of load cycles

- variation of stress ratio ( $\left.q / p^{\prime}\right)$ with axial strain during the extension stage

The resilient modulus is defined as the cyclic change in deviator stress divided by the recoverable (resilient) axial strain during unloading in a triaxial test [29]. Changes in specimen height rather than vertical strains are used because of the coarse grained nature of the scaled ballast, and to aid interpretation of lift relative to grain size.

\section{Triaxial test}

\subsection{Trackbed loading - basis for applied stress in triaxial tests}

The cycles of stress applied in the testing represented the stress paths followed by an element of ballast immediately beneath a railway sleeper, below the rail (Figure 9).

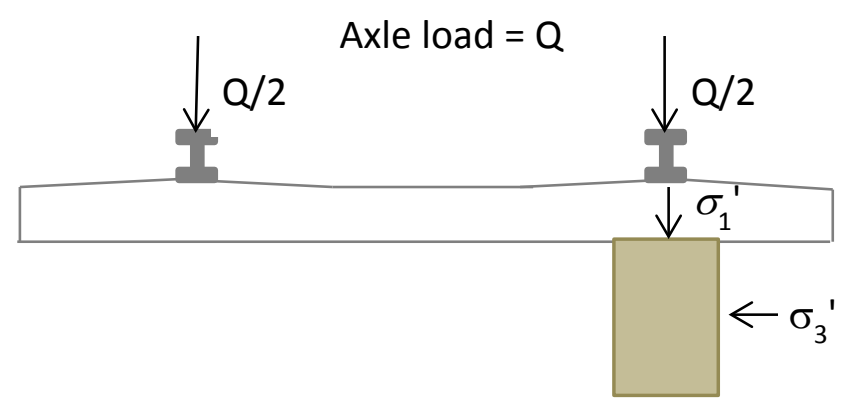

Figure 9: Element of ballast

Stress transfer from the wheel through the rail and into the ballast depends on the bending stiffness of the rail and the sleeper, the properties of the railpad and the support stiffness of 


\section{Modelling the effects of trafficking and tamping on scaled railway ballast in triaxial tests}

the trackbed. Seed et al., [30] reported a maximum sleeper base vertical contact stress beneath the railseats of $200 \mathrm{kPa}$ to $270 \mathrm{kPa}$ under a $200 \mathrm{kN}$ axle load. Stewart et al., [31] carried out box tests to investigate horizontal stresses in the ballast under a vertical repeated loading of $270 \mathrm{kPa}$ at the ballast surface. Pressure cells in the sides of the box indicated horizontal stresses in the ballast immediately below the surface of $20 \mathrm{kPa}$ (unloaded) and $60 \mathrm{kPa}$ (loaded). However, as the cycles of load continued (to 10,000 when the test was terminated,) the variation in horizontal stress narrowed to $27 \mathrm{kPa}$ and $31 \mathrm{kPa}$. Other researchers have reached generally similar conclusions e.g. [15, 16, 32, 33, 34 and 35].

\subsection{Testing Programme}

The tests comprised approximately 1000 cycles of vertical loading (simulating trafficking), followed by either one or ten loading cycles in which the lateral stress was increased then decreased while the vertical stress was held constant (simulating the change in direction of major principal stress caused by tamping), and then a further 1000 to 1925 vertical loading cycles to simulate the effect of trafficking immediately after. The number of load cycles applied was relatively few compared with the numbers of load cycles in reality, but was sufficient to evaluate behavioural trends.

Two types of cyclic traffic loading were applied

i. The cell pressure was held constant while the vertical stress was cycled

ii. The cell pressure and vertical stress were cycled simultaneously.

Vertical (axial) load was generally cycled with a period of 5 minutes, except for the first two cycles for which a period of 10 minutes was used to allow bedding in.

The test parameters and the load paths applied are shown in Table 1.

\begin{tabular}{|c|c|c|c|c|c|c|c|c|c|}
\hline \multirow[t]{2}{*}{$\begin{array}{l}\text { Test } \\
\text { label }\end{array}$} & \multirow[b]{2}{*}{$\begin{array}{l}\text { Initial } \\
\text { Density } \\
\left(\mathrm{kg} / \mathrm{m}^{3}\right)\end{array}$} & \multicolumn{3}{|c|}{$\begin{array}{l}\text { Vertical Cyclic stress } \\
\text { paths }\end{array}$} & \multirow[b]{2}{*}{$\begin{array}{l}\text { Initial } \\
\text { number } \\
\text { of cycles }\end{array}$} & \multicolumn{3}{|c|}{ Extension stage loading } & \multirow[b]{2}{*}{$\begin{array}{l}\text { Furth } \\
\text { er } \\
\text { cycles }\end{array}$} \\
\hline & & $\begin{array}{l}\sigma_{3}^{\prime}- \\
(\mathrm{kPa})\end{array}$ & $\mathrm{q}(\mathrm{kPa})$ & $\begin{array}{l}\left(\sigma_{1}{ }^{\prime}\right) \\
\left.\sigma_{3}{ }^{\prime}\right) \\
\text { at } \\
\mathrm{q}_{\max }\end{array}$ & & $\sigma_{3}^{\prime}(\mathrm{kPa})$ & cycles & $\sigma_{1}^{\prime}(\mathrm{kPa})$ & \\
\hline $\mathrm{T} 1$ & 1549 & $15-45$ & $5-225$ & 6 & 1000 & \multicolumn{4}{|l|}{$\mathrm{N} / \mathrm{A}$} \\
\hline $\mathrm{T} 2$ & 1550 & $15-45$ & $5-225$ & 6 & 1000 & $45-200$ & 1 & 50 & None \\
\hline T3 & 1528 & 45 & $5-225$ & 6 & 1000 & $45-200$ & 1 & 50 & None \\
\hline T4 & 1536 & 55 & $5-225$ & 5.09 & 1000 & $55-210$ & 10 & 60 & 1600 \\
\hline T5 & 1543 & 55 & $5-225$ & 5.09 & 1000 & $55-225$ & 1 & 60 & 1000 \\
\hline T6 & 1583 & 55 & $5-225$ & 5.09 & 1000 & $55-225$ & 1 & 60 & 1925 \\
\hline
\end{tabular}

Table 1: Cyclic test parameters 


\section{Modelling the effects of trafficking and tamping on scaled railway ballast in triaxial tests}

Tests T1 and T2 included cell pressure cycles intended to reflect the increase/decrease in lateral (confining) stress at low numbers of cycles seen in the work by Stewart et al., [31] and were considered to be more realistic, of how the stresses cycle in the trackbed initially. In tests T3 to T6 a constant confining stress of either $45 \mathrm{kPa}$ or $55 \mathrm{kPa}$ was applied representing a maximum confining stress per cycle in a conventional triaxial test. . Monotonic tests on the same scaled ballast gave peak stress ratios approaching 7.5 and peak angles of shearing resistance approaching $50^{\circ}$ at low $(15 \mathrm{kPa})$ confining stress [26]. Considering the likely loading (section 4.1) and the material properties determined in monotonic tests, the stress ratio was set not to exceed 6 in any test. This represents a mobilised effective shearing angle of $46^{\circ}$ and was considered to be close to the limit for long term cyclic stability of the scaled ballast tested.

\subsection{Triaxial Results}

Figures 10 to 12 show the variation in specimen height with the number of loading cycles. In each case the initial height was $300 \mathrm{~mm}$. In the only cycled extension test stage applied (T4) the major change in height occurred during the first extension cycle and therefore the results of this test are similar to those where only a single cycle of extension loading was applied (T2, T3, T5 and T6). The thickness of the line representing the main loading cycle is due to the full cycle being plotted, hence indicates the resilient change in height over each cycle (generally 0.3 to $0.4 \mathrm{~mm}$ ).
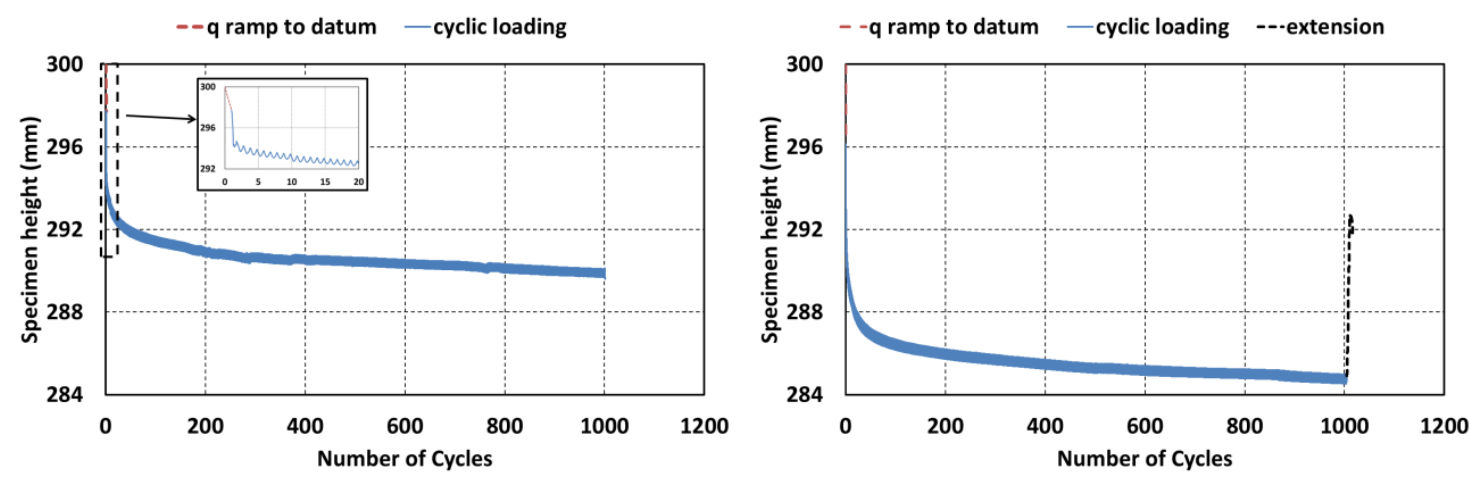

Figure 10: Specimen height against number of cycles (a) T1 (b) T2 


\section{Modelling the effects of trafficking and tamping on scaled railway ballast in triaxial tests}
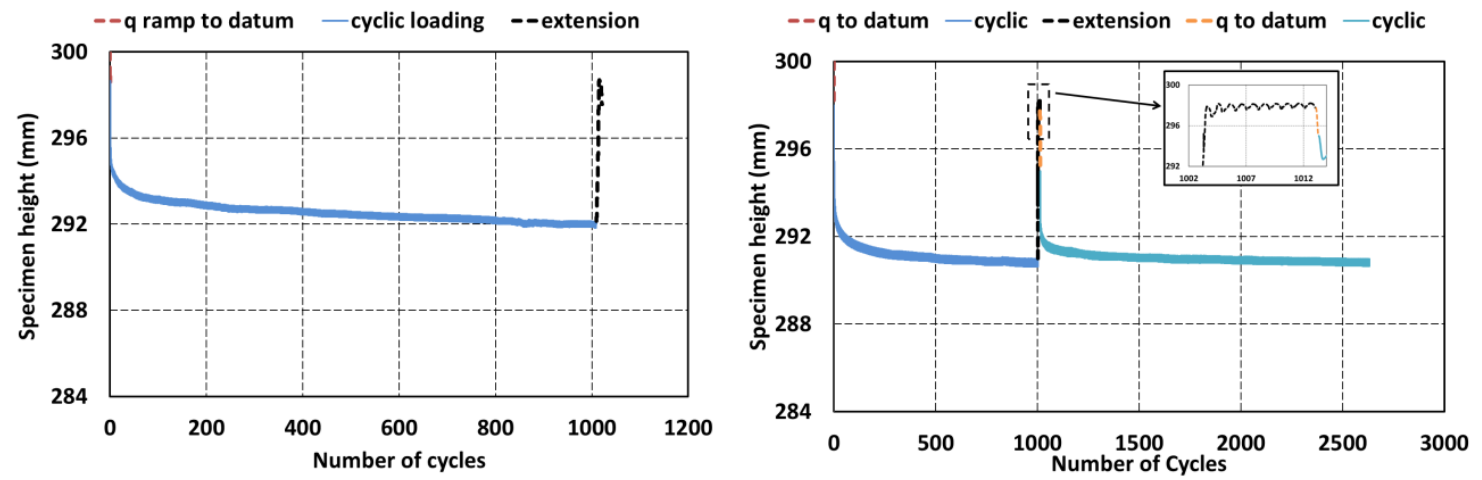

Figure 11: Specimen height against number of cycles (a) T3 (b) T4
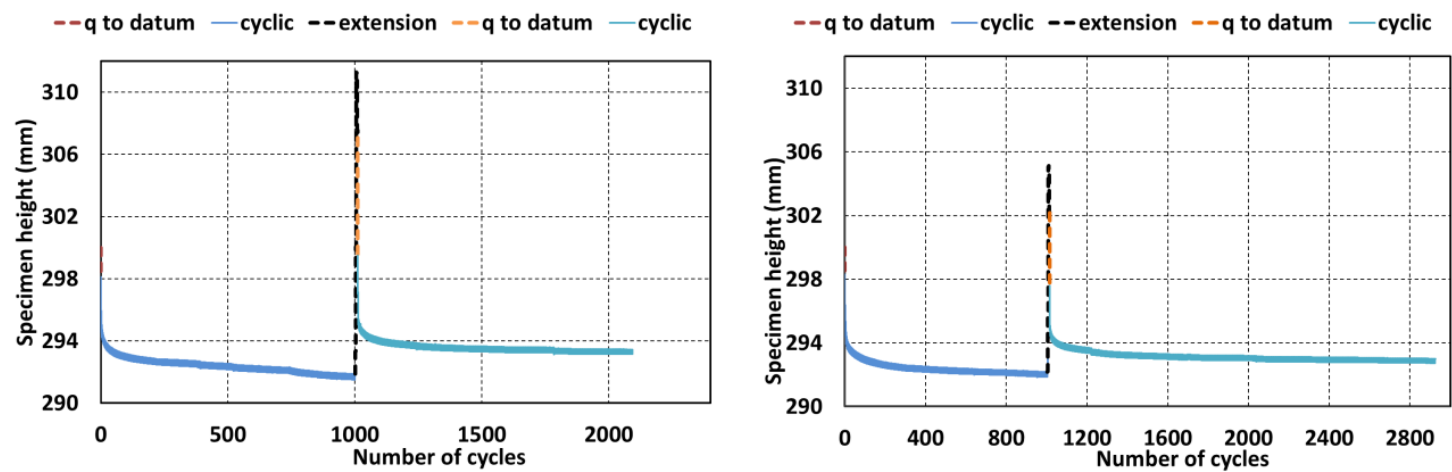

Figure 12: Specimen height against cycles (a) T5 (b) T6

Tests T1 and T2 show greater reductions in height during the initial 1000 vertical loading cycles than tests T3 to T6. This was largely due to the more onerous cyclic loading in tests T1 and $\mathrm{T} 2$ in which both principal stresses were cycled. The increase in height during the extension stage varied between tests even where the applied stresses were the same, indicative of a natural variation between specimens. For tests T2, T3 and T4 the extension stage was calibrated to return the specimen height close to its initial value. However, owing to the greater height reduction during the initial 1000 cycles, specimen T2 only recovered about half the height lost. Specimens T3 and T4 reduced in height by similar amounts during the initial 1000 cycles and the extension stages returned the heights close to the initial value.

The extension stages for specimens T5 and T6 imposed more onerous loading conditions than the extension stages of tests $\mathrm{T} 2$ to $\mathrm{T} 4$, which increased the specimen heights to above their initial values. After the extension stages in tests T4 to T6, a significant reduction in height occurred on the first subsequent cycle of vertical loading. With continuing cycles, the specimen heights tended to their values prior to the extension stage, although for those samples lifted above their initial height the final height remained at least slightly above the final pre-extension stage value. This confirms the observation by Selig and Waters (1994) that a tamping lift of at least the average ballast grain size ( $12 \mathrm{~mm}$ for scaled ballast) is needed to show a lasting improvement in track geometry. 


\section{Modelling the effects of trafficking and tamping on scaled railway ballast in triaxial tests}

Figures 13 and 14 show the resilient modulus plotted against number of cycles. After initial bedding in, resilient moduli stabilised at typically $200 \mathrm{MPa}$ to $250 \mathrm{MPa}$ in tests T3 to T6 and $150 \mathrm{MPa}$ in tests T1 and T2 with their lower average cell pressures.

The resilient modulus drops after the extension stage, consistent with the loosening of the compacted ballast layer during tamping. With continuing stress cycles the resilient modulus recovers towards its pre-extension stage value.
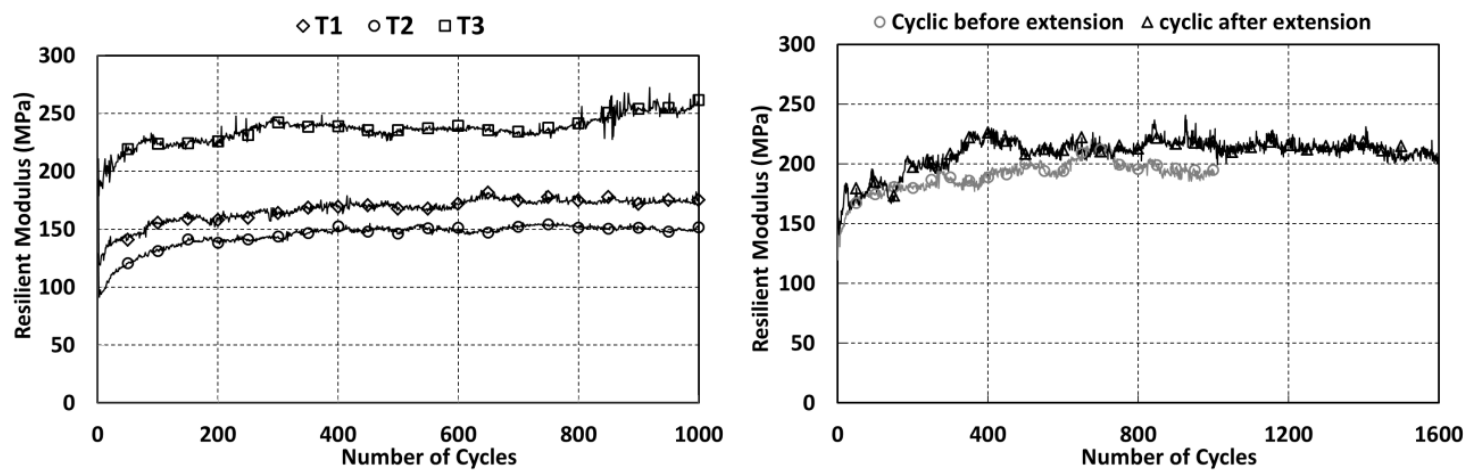

Figure 13: Resilient modulus for (a) T1 T2 and T3 with no extension stage (b) T4 pre and post extension
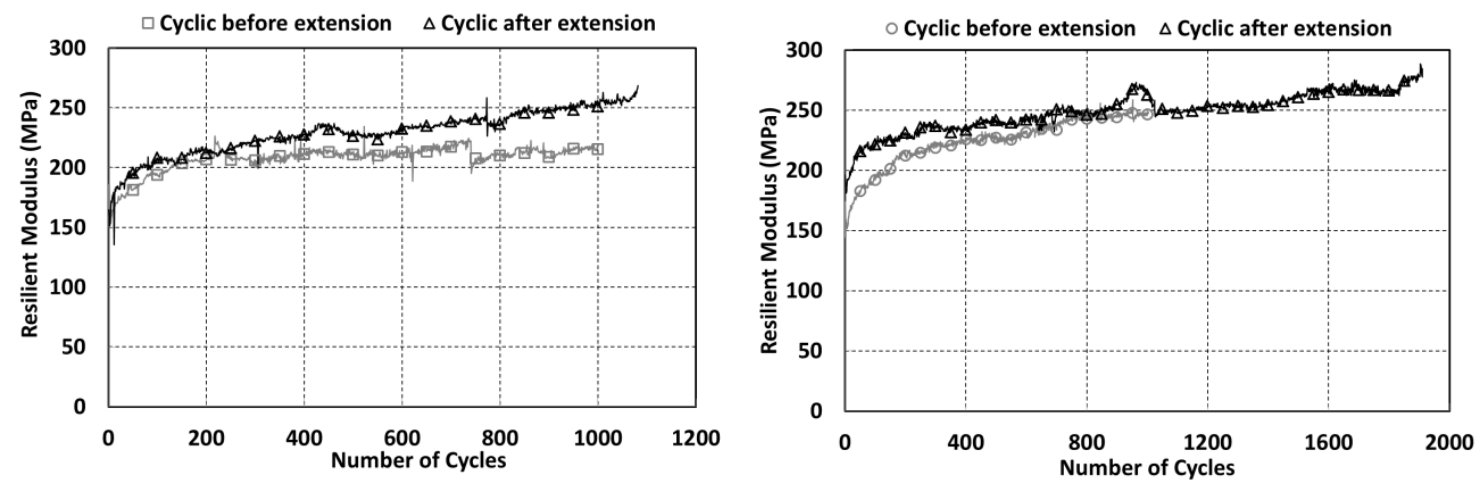

Figure 14: Resilient modulus pre and post extension for (a) T5 (b) T6

Figure 15 shows graphs of stress ratio against axial strain for the extension stage stress cycles in tests T2 to T6. The axial strains were re-zeroed at the start of the extension stage so that each stress path starts from the origin. 


\section{Modelling the effects of trafficking and tamping on scaled railway ballast in triaxial tests}
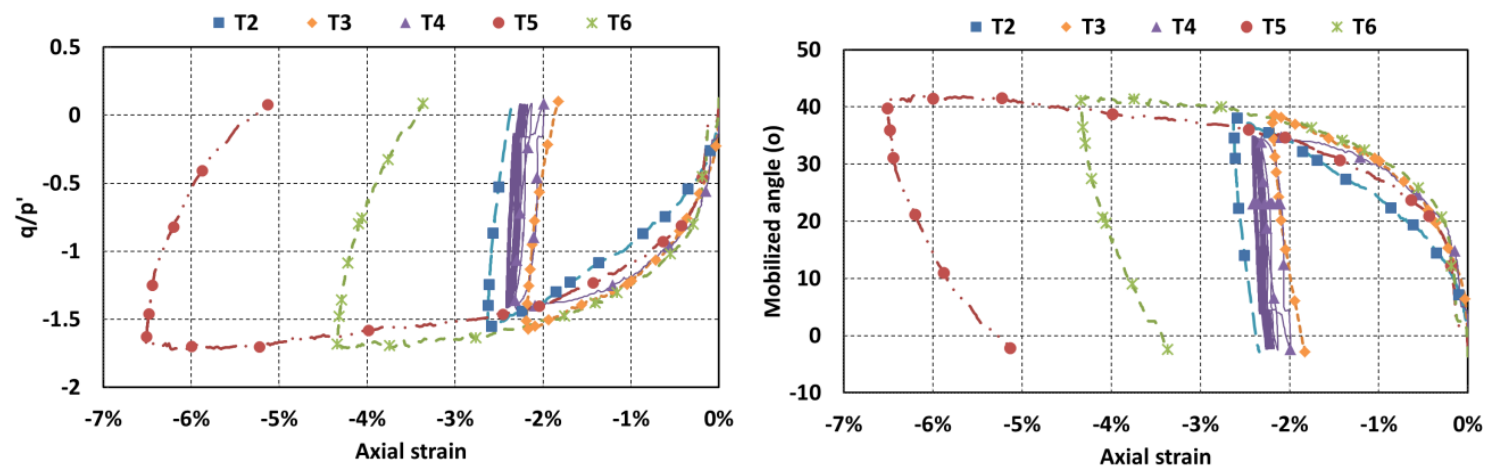

Figure 15: Extension stage (a) $q / p^{\prime}$ against axial strain (b) Mobilized friction angle against axial strain

Figure 15 shows that all the specimens followed a broadly similar stress strain path. It also highlights the effect of the slightly more onerous deviator stress increment applied, which resulted in significantly greater axial strains in tests T5 and T6 (Table 1) than in the other tests.

\section{Conclusions}

The triaxial tests have provided data on settlement, stiffness and the effects of simulated tamping, showing that:

- Initial cycles of loading produce more significant settlements than subsequent cycles

- Cycling both principal stresses causes reduced stiffness and greater settlement than cycling the major principal stress alone

- After an extension stage simulating tamping, the trends of stiffness and settlement with number of vertical loading cycles quickly return to their previous paths

- Overlifting during the extension/simulated tamping stage is required to maintain the ballast level above its pre-tamped level as the number of subsequent verticalloading cycles increases.

This study has highlighted a potential unintended consequence of tamping maintenance of ballasted railway track, i.e. the loss of resilient stiffness and resistance to vertical loading caused by changes in the major principal stress direction from vertical to horizontal disrupting the ballast structure. Given the initially high rates of settlement after simulated tamping, which are comparable to that for the initially placed material, tamping should ideally be carried out as rarely as possible.

\section{Acknowledgements}

The authors are grateful for the financial support of the Engineering and Physical Sciences Research Council (EPSRC) through two grants. (1) "Development and role of structure in railway ballast", EP/F062591/1 \& (2) the Programme grant TRACK21 (EP/H044949/1. All data 


\section{Modelling the effects of trafficking and tamping on scaled railway ballast in triaxial tests}

supporting this study are openly available from the University of Southampton repository at https://doi.org/10.5258/SOTON/D0509

\section{References}

[1] Selig, E. T. \& Waters, J. M. 1994. Track Geotechnology and Substructure Management, London, Telford.

[2] Selig, E. T. \& Sluz, A. 1978. Ballast and Subgrade Response to Train Loads. Transportation Research Record, 694, 53-60.

[3] Selig, E. T. 1980. Ballast Research. In Proc: Proceedings, Technical Conference - American Railway Engineering Association, Chicago, IL, USA. 81, 504-520, Am Railw Eng Assoc, Washington, DC

[4] Burks, M. E., Robson, J.D., \& Shenton, M.J. 1975. Comparison of robel supermat and plasser 07-16 track maintenance machines. Tech.note TN SM 139, British Railways Board $R$ \& D Division, December

[5] Wright, S. E. 1983. Damage caused to ballast by mechanical maintenance techniques. British Rail Research Technical Memorandum TM TD 15, May.

[6] Chrismer, S. M. 1989. Track surfacing with conventional tamping and stone injection. Association of American Railroads Research Report No. R-719. Chicago, Illinois

[7] Milne, D., Le Pen, L., Watson, G., Thompson, D., Powrie, W., Hayward, M. \& Morley, S. 2018. Defect repair strategies for ballasted railway track. Unpublished Manuscript, Faculty of Engineering and the Environment, University of Southampton.

[8] Brewer R., 1964, "Fabric and mineral analysis of soils", New York: John Wiley and Sons Inc,

[9] Oda, M., 1972a. Deformation mechanism of sand in triaxial compression tests. Soils and Foundations, 12(4), pp.45-63.

[10] Oda, M., 1972b, "Initial fabrics and their relations to mechanical properties of granular material", Soils and Foundations, 12(1).

[11] Burland, J. B., 1990, "On the compressibility and shear strength of natural clays", Geotechnique, Volume 40, No. 3, pages 329 to 378.

[12] Oda, M., \& Iwashita, K., (editors) 1999. “Mechanics of granular materials: an introduction", Rotterdam, A.A. Balkema.

[13] O'Brien A., Ellis, E. A., \& Russell, D., 2004, "Old railway embankment fill laboratory experiments, numerical modelling and field behaviour", In Proc: Advances in Geotechnical Engineering. The Skempton Conference, Volume 2, pp. 911-921, London: Thomas Telford 


\section{Modelling the effects of trafficking and tamping on scaled railway ballast in triaxial tests}

[14] Watters, B., Klassen, M. \& Clifton, A. 1987. Evaluation of Ballast Materials using Petrographic Criteria. Transportation Research Record, 1131, Performance of Aggregates in Railroads and Other Track Performance Issues, 45-63.

[15] Raymond, G. P. \& Williams, D. R. 1978. Repeated load Triaxial Tests on a Dolomite Ballast. Journal of The Geotechnical Engineering Division, ASCE, 104, 1013-1029.

[16] Lackenby, J., Indraratna, B., Mcdowell, G. R. \& Christie, D. 2007. Effect of confining pressure on ballast degradation and deformation under cyclic triaxial loading. Géotechnique, $57,527-536$.

[17] Suiker, A. S. J., Selig, E. T. \& Frenkel, R. 2005. Static and Cyclic Triaxial Testing of Ballast and Subballast. Journal of Geotechnical and Geoenvironmental Engineering, 131, 771-782..

[18] Anderson, W. F. \& Fair, P. 2008. Behaviour of Railroad Ballast under Monotonic and Cyclic Loading. Journal of Geotechnical and Geoenvironmental Engineering, ASCE, Vol 134, 316 to 327.

[19] Aursudkij, B., Mcdowell, G. R. \& Collop, A. C. 2009. Cyclic loading of railway ballast under triaxial conditions and in a railway test facility. Granular Matter, 11, 391 to 401.

[20] Sevi, A. \& Ge, L. 2012. Cyclic Behaviors of Railroad Ballast within the Parallel Gradation Scaling Framework. Journal of Materials in Civil Engineering, 24, 797-804.

[21] Abadi, T., Le Pen, L., Zervos, A. \& Powrie, W. 2016. A Review and Evaluation of Ballast Settlement Models using Results from the Southampton Railway Testing Facility (SRTF). Procedia Engineering, 143, 999-1006.

[22] Abadi, T., Pen, L. L., Zervos, A. \& Powrie, W. 2018. Improving the performance of railway tracks through ballast interventions. Proceedings of the Institution of Mechanical Engineers, Part F: Journal of Rail and Rapid Transit, 232, 337-355.

[23] Lowe, J. 1964. Shear Strength of Coarse Embankment Dam Materials. Proceedings, 8th Congress on Large dams, pp. 745-761.

[24] Le Pen, L., Powrie, W., Zervos, A., Ahmed, S. \& Aingaran, S. 2013. Dependence of shape on particle size for a crushed rock railway ballast. Granular Matter, Springer Berlin Heidelberg.

[25] Le Pen, L., Bhandari, A. \& Powrie, W. 2014. Sleeper End Resistance of Ballasted Railway Tracks. Journal of Geotechnical and Geoenvironmental Engineering, 140, 04014004; 1-14.

[26] Aingaran, S. 2014. Experimental investigation of static and cyclic behaviour of scaled railway ballast and the effect of stress reversal. Ph.D. dissertation, Faculty of Engineering and the Environment, Univ. of Southampton, Southampton, U.K. 


\section{Modelling the effects of trafficking and tamping on scaled railway ballast in triaxial tests}

[27] GDS Instruments. 2015. Triaxial Automated System (Load Frame type) [Online]. Available: http://www.gdsinstruments.com/gds-products/triaxial-automated-system-loadframe-type [Accessed February 2018].

[28] Marachi, N. D., Chan, C. K. \& Seed, H. B. 1972. Evaluation of Properties of Rockfill Materials. Journal of the Soil Mechanics and Foundations Division, Proceedings of the American Society of Civil Engineers, 98, 95-114.

[29] Shenton, M. J. 1975. Deformation of Railway Ballast under Repeated Loading Conditions. In: KERR (ed.) Railroad Track Mechanics and Technology. Proceedings of a symposium held at Princeton University, USA, pp. 387-404.

[30] Seed, H., Chan, C., Lee, C., TRANSPORTATION, I. O. \& ENGINEERING, T. 1962. Resilience characteristics of subgrade soils and their relation to fatigue failures in asphalt pavements, Institute of Transportation and Traffic Engineering, University of California.

[31] Stewart, H. E., Selig, E. T. \& Norman-Gregory, G. M. 1985. Failure Criteria and Lateral Stresses in Track Foundations. Transportation Research Record, 1022, 59-64.

[32] Powrie, W., Yang, L. A. \& Clayton, C. R. I. 2007. Stress changes in the ground below ballasted railway track during train passage. Proceedings of the Institution of Mechanical Engineers, Part F (Journal of Rail and Rapid Transit), 221, 247-61.

[33] Indraratna, B. \& Salim, W. 2005. Mechanics of Ballasted Rail Tracks, a Geomechanical Perspective, London, UK, Taylor \& Francis Group plc.

[34] Le Pen, L. 2008. Track Behaviour: The Importance of The Sleeper to Ballast Interface, Thesis. Department of Civil and Environmental Engineering, University of Southampton.

[35] Indraratna, B., lonescu, D. \& Christie, H. D. 1998. Shear behavior of railway ballast based on large-scale triaxial tests. Journal of Geotechnical and Geoenvironmental

Engineering, 124, 439. 